\title{
Geoinformation system as a controlling tool for External State Audit Bodies
}

\author{
Anna Zueva*1 \\ ${ }^{1}$ Lomonosov Moscow State University, Moscow, Russia, dgastin@mail.ru
}

\begin{abstract}
The Author justifies the needs of introducing Geo-Informational Systems into the daily activities of The External State Audit Bodies by revealing the concepts of both controlling and digital audit applications. With the development of introducing digital auditing into The Accounting Chamber of The Russian Federation along with Russia's leadership role in INTOSAI, the time has come to modernize our information systems for the 21 st century and beyond.
\end{abstract}

\section{Keywords}

External State Audit Bodies, Digital Earth, Geoinformation system.

\section{Introduction}

The idea of digital audit is actively developing both at the level of the private sector and at the state level. The use of information technologies in the process of performing audit activities should increase its effectiveness.

\section{Discussion}

The Digital Audit uses new technology to deliver high-quality audits that serve the public interest by enhancing trust and confidence.

Today, digital audit is being developed and applied in two directions:

1. in private companies. For example, PWC, EY, KPMG;

2. in the activities of state financial control and state audit bodies.

INTOSAI (International Organization of Supreme Audit Institutions) occupies a special place in this process.

At the XIII Congress of the International Organization of Supreme Audit Institutions (INCOSAI) in Berlin in 1989, The Working Group on Information Technology Audit (WGITA) was created to address SAI's interests in the area of IT Audit. Supreme Audit Institutions (SAIs) of 39 countries represents the Working Group as of March 2013 (INTOSAI, 2020).

The WGITA fulfills its mission and mandate by implementing the triennial work plan which consists of the various goals and projects. Projects are selected after reviewing the needs of SAIs and the deliverable range from the best practice guides to website related information and other

\footnotetext{
Corresponding author
} 
audit material. It is the dedication and effort of individual SAIs, who lead and support projects, as project leaders and members, that make the WGITA work.

The mission of the WGITA is to support SAIs in developing their knowledge and skills in the use of information technology related audits by providing information and facilities for exchange of experiences, sharing best practices, and encouraging bilateral and regional cooperation among Supreme Audit Institutions (SAIs).

From the perspective of the development of the audit function, Supreme Audit Institutions (SAIs) worldwide have undertaken increasingly important duties in strengthening accountability, promoting good governance, and monitoring the implementation of sustainable development goals in their respective countries. The XXII Congress of the International Organization of Supreme Audit Institutions (INCOSAI) in 2016 adopted "How can INTOSAI contribute to the UN 2030 Agenda for Sustainable Development, including good governance and strengthening the fight against corruption?” as the topic for Theme I. In its Strategic Plan 2017-2022, INTOSAI mapped out a clear vision to "promote good governance by enabling SAIs to help their respective governments improve performance, enhance transparency, ensure accountability, maintain credibility, fight corruption, promote public trust, and foster the efficient and effective receipt and use of public resources for the benefit of their citizens." In the era of Big Data, SAIs are aware of the importance of information technology to improve audit quality so as to help their respective countries implement their sustainable development strategies.

Digital audit makes it possible to follow the trace of economic activities in digital circumstances, so that SAIs can evaluate the performance, transparency, and accountability of the public sector in a more accurate and prompt manner, and ultimately facilitate the implementation of the United Nations' 2030 Agenda for Sustainable Development.

One of the themes of INCOSAI XXIII held in Moscow in 2019 was the role of information technologies in public administration. The Accounts Chamber of the Russian Federation proposed this topic for consideration by the INCOSAI understanding that quality control of public investments in the modern world is impossible without the introduction and application of advanced digital solutions and analytical methods.

The international audit community recognizes the need for "an efficient use of the opportunities brought about by the technological progress." In particular, it is Big Data received from public bodies, progressive analysis of digital data as well as the artificial intelligence and other solutions at different stages of an audit. 
The accounts chamber of Russia will be able to switch to digital audit within three years. This was announced by the head of the Department Alexey Kudrin in 2018. "First of all, this is the digitalization of financial audit. Much of this work is already based on the results of an automatic analysis of the electronic budget, but in general, we will seriously advance the analysis of the work of all institutions. We will cover significantly more, even without going out for on-site audits. He state that, It will take about three years to make serious progress in this area to put it into permanent practice with expanded coverage", Kudrin said (TASS.ru, 2018). Digitalization of the audit will significantly reduce the number of violations allowing the audit chamber to switch to a preventive mode of operation.

In 2015, the audit chamber created the official website of the Russian Federation in the information and telecommunications network "Internet" for posting information on the implementation of state (municipal) financial audit (control) in the field of budgetary legal relations. The creation of this portal is aimed at coordinating the activities of controlling financial authorities and informing citizens about the activities of control accounting bodies.

As part of the development of the idea of implementing information technologies in the activities of higher audit bodies, it is advisable to use GIS.

A geographic information system (GIS) is a system for collecting, storing, analyzing, and graphically visualizing spatial (geographical) data and related information about required objects. GIS integrates many types of data. It analyzes spatial location and organizes layers of information in visualizations using maps and 3D scenes. With this unique capability, GIS reveals a deeper understanding of data such as patterns, relationships, and situations, helping users make smarter decisions (ESRI.com, 2020).

GIS combines many different types of data layers using spatial arrangement. Most of the data has a geographical component. GIS data includes images, objects, and basemaps.

Spatial analysis allows you to assess suitability and capabilities, evaluate and predict, interpret and understand, and much more, providing new perspectives to your understanding and decision-making process.

Apps provide a focused user experience to get the job done and bring GIS to life for everyone.

Governments collect and manage vast amounts of data - all tied to location. Maps and spatial analysis are quick to understand, so it's easier to use. Making decisions based on data that improve the quality of life is important for national, state and local governments. The use of GIS by 
government agencies contributes to improving the quality of controlling and the effectiveness of management decisions. The control and accounting authorities of Russia should use GIS for monitoring and controlling the expenditure of budget funds and for more detailed budget planning.

Geoinformation systems in the activities of Supreme Audit Institutions consist of 4 parts: Insightful analytics, Simplified sharing, Rapid data collection, Coordinated response.

Insightful analytics which is the ability to create and share easy-to-use maps and analytics that improve everyone's understanding. Analyze complex issues and reveal hidden patterns in data. Facilitating informed decision-making.

Simplified sharing the sharing of maps and analytics securely with staff or citizens to support smart initiatives. Dashboards, story maps, interactive web maps, and infographics provide intuitive and effective communication tools.

Rapid data collection the simplification of data collection on any device, including smartphones, drones, and Internet of Things (IoT) sensors. Quickly assembles data from real-time feeds, multiple databases, or any online public data repository.

Coordinated response that covering the Synchronization of first responders with real-time status data and maps in a single, unified dashboard. Acts with confidence in dynamically changing situations to speed assistance and to keep people safe.

\section{Conclusions}

The use of GIS in state audit will allow you to track the effectiveness of budget spending in real time. The accounts chamber will be able to see the process of spending Federal budget funds and implementation of state programs in each region of the country, using artificial intelligence to analyze information and develop recommendations for improving internal financial control and audit.

\section{References}

INTOSAI (2020) WGITA URL: http://175.28.13.77/working_group_directories/1 Accessed 30 Dec 2020

Coulibaly L, Labib ME, Hazen R (2004) A GIS-based multimedia watershed model: development and application // Chemosphere. T. 55. № 7. C. 1067-1080. 
ESRI.com (2020) URL: http://esri.com Accessed 30 Dec 2020

TASS.ru (2018) The Chamber of Accounts will switch to digital auditing within three years (Russian) URL: https://tass.ru/ekonomika/5423538 Accessed 30 Dec 2020

Touq AB (2016) The UAE Federal Government's e-participation roadmap: developments in UAE empowerment initiatives with VGI/PGIS and location based services (LBS). Innovation Management and Technology in the Era of Globalization. Materials of the III International scientific-practical conference. pp. 116-134. 